\title{
PENGUNDANGAN PERATURAN LEMBAGA NEGARA INDEPENDEN DI INDONESIA (ANALISIS TERHADAP POLEMIK PENGUNDANGAN PERATURAN KOMISI PEMILIHAN UMUM NOMOR 20 TAHUN 2018
}

(Promulgation of the Independent Agencies Regulation in Indonesia (Analysis of Promulgation Polemic of General Elections Commission Regulation Number 20 of 2018)

\author{
Gunardi SA Lumbantoruan \\ Badan Pembinaan Hukum Nasional Kementerian Hukum dan Hak Asasi Manusia \\ email: gunardisalt@gmail.com
}

Naskah diterima: 24 Agustus 2020; revisi: 10 November 2020; disetujui: 11 November 2020

\begin{abstract}
Abstrak
Polemik pembentukan PKPU No. 20 Tahun 2018 menjadi pemberitaan nasional. Sikap Menkumham yang menolak permohonan awal pengundangan dan mengembalikan rancangan peraturan tersebut menjadi bahan perdebatan. Rumusan masalah yang diangkat dalam penulisan ini adalah, pertama: bagaimana konsepsi dan tata cara pengundangan, kedua: bagaimana pengundangan peraturan lembaga negara independen, ketiga: bagaimana pelaksanaan kewenangan Menkumham dalam pengundangan Peraturan KPU Nomor 20 Tahun 2018 ditinjau dari hukum administrasi negara. Penulisan ini menggunakan metode penelitian yuridis normatif, dengan pendekatan perundang-undangan, konseptual, dan kasus. Penulisan ini menyimpulkan bahwa secara konsepsi, pengundangan berkaitan dengan daya ikat dan daya laku peraturan. Dalam proses pengundangan pada Lembaran Negara dilakukan pemeriksaan administratif, sedangkan dalam proses pengundangan pada Berita Negara dilakukan pemeriksaan administratif dan substantif. Terdapat peraturan lembaga negara independen yang diundangkan dalam Lembaran Negara, diundangkan dalam Berita Negara, dan tidak diundangkan sama sekali. Ditinjau dari hukum administrasi negara, sikap Menkumham bukan merupakan tindakan onbevoegd (tidak berwenang) dan secara umum masih sesuai dengan AAUPB. Terkait hal tersebut maka perlu pengaturan persyaratan, tata cara, dan batasan waktu pengundangan pada UU tentang Pembentukan Peraturan Perundang-undangan. Sembari menunggu hal tersebut, pihak yang berkepentingan dapat melakukan uji materi terhadap "Permenkumham Pengundangan" apabila diperlukan.

Kata Kunci: pengundangan, lembaga negara independen, administrasi, KPU
\end{abstract}

\begin{abstract}
Legislation polemic of "PKPU" No. 20 Tahun 2018 has become national news. "Menkumham's responds, which rejected the initial promulgation request and returning the regulation draft, became a matter of debate. The formulation of this writing problem is, first: what is the conception and procedures of promulgation?, second: how is the promulgation of independent agencies regulations?, third: how is the implementation of Menkumham's authority on promulgation of "PKPU" No. 20 Tahun 2018 in administrative law view?. This writing uses normative juridical research methods, with statute, conceptual, and case approach. This writing conclude that: conceptionally, promulgation is related to binding power and enforceability. There are independent agencies regulation that promulgated on state gazette, promulgated on state bulletin, and not promulgated at all. Promulgation on the state bulletin is subject to administrative and substantive review. Reviewed on administrative law view, "Menkumham's responds is not an act of onbevoeg (not authorized) and its generally in accordance with "AAUPB". Related to this it is necessary to regulate the requirements, procedures, and time limits of the promulgation on Legislation Act. In the meantime, Interested parties can conduct a judicial review of "Permenkumham Pengundangan" if necessary.
\end{abstract}

Keywords: promulgation, independent agencies, administration, KPU 


\section{A. Pendahuluan}

Polemik pembentukan Peraturan Komisi Pemilihan Umum Nomor 20 Tahun 2018 tentang Pencalonan Anggota Dewan Perwakilan Rakyat, Dewan Perwakilan Rakyat Daerah Provinsi, dan Dewan Perwakilan Rakyat Daerah Kabupaten/Kota (Peraturan KPU No. 20 Tahun 2018), menjadi berita nasional dan diperdebatkan di kalangan akademisi, politisi, dan birokrat. Substansi pengaturan yang diperdebatkan pada Peraturan KPU No. 20 Tahun 2018 tersebut adalah ketentuan Pasal 7 ayat 1 huruf $h$, yakni mengenai larangan mantan terpidana korupsi menjadi calon legislatif. Polemik ini terjadi karena Komisi Pemilihan Umum (KPU) bersikeras untuk mengatur larangan bagi mantan terpidana korupsi menjadi calon legislatif melalui Rancangan Peraturan KPU No. 20 Tahun 2018. Namun Pemerintah, DPR, dan Bawaslu menilai bahwa substansi pengaturan pada Pasal 7 ayat 1 huruf $h$ tersebut tidak dapat diatur pada Peraturan Komisi Pemilihan Umum (Peraturan KPU) karena sifatnya membatasi hak orang lain. Selain itu, Pasal 7 ayat 1 huruf $h$ Rancangan Peraturan KPU No. 20 Tahun 2018 tersebut juga dinilai bertentangan dengan Pasal 240 ayat 1 huruf g Undang-undang Nomor 7 tahun 2017 tentang Pemilihan Umum, serta dianggap melawan Putusan Mahkamah Konstitusi Nomor 42/ PUU-XIII/2015².

Substansi pengaturan Pasal 7 ayat 1 huruf h Rancangan Peraturan KPU No. 20 Tahun 2018 tersebut sebenarnya telah dibahas dalam rapat konsultasi antara KPU dengan Pemerintah yang diwakili kementerian dalam negeri, Komisi II DPR, dan Bawaslu, namun pada rapat tersebut tidak tercapai kesepakatan. Berdasarkan Putusan Mahkamah Konstitusi Nomor 92/PUU-XIV/2016³, kesimpulan rapat konsultasi tersebut memang tidak mengikat, sehingga KPU tetap dapat melaksanakan kewenangannya dalam membuat Peraturan KPU, sebab KPU bertanggung jawab untuk menjamin penyelenggaraan pemilihan umum yang demokratis. Atas dasar hal tersebut, setelah mengadakan rapat pleno komisioner,

CNN Indonesia, "Kukuh Larang Eks Koruptor Nyaleg, KPU Siap Hadapi Gugatan", https://www.cnnindonesia. com/nasional/20180523141414-32-300626/kukuh-larang-eks-koruptor-nyaleg-kpu-siap-hadapi-gugatan (diakses 20 Juli 2020).

2 Putusan Mahkamah Konstitusi Nomor 42/PUU-XIII/2015 ini menyatakan bahwa Pasal 7 huruf g Undang-Undang Nomor 1 Tahun 2015 Tentang Perubahan Atas Undang-Undang Nomor 1 Tahun 2015 Tentang Penetapan Peraturan Pemerintah Pengganti Undang-Undang Nomor 1 Tahun 2014 Tentang Pemilihan Gubernur, Bupati, Dan Walikota Menjadi Undang-Undang, bertentangan dengan Undang-Undang Dasar Negara Republik Indonesia Tahun 1945 secara beryarat sepanajng tidak dimaknai dikecualikan bagi mantan terpidana yang secara terbuka dan jujur mengemukakan kepada publik bahwa yang bersangkutan mantan terpidana. Dalam pertimbangannya MK berpendapat bahwa ketika seorang mantan narapidana selesai menjalankan masa tahanannya dan mengumumkan secara terbuka dan jujur bahwa dia adalah mantan narapidana, maka yang bersangkutan dapat mencalonkan diri dalam jabatan publik atau jabatan politik yang pengisiannya melalui pemilihan (elected officials). Namun apabila mantan narapidana tersebut tidak mengemukakan kepada publik bahwa yang bersangkutan adalah mantan terpidana, maka berlaku syarat kedua putusan MK Nomor 4/PUU-VII/2009, yaitu lima tahun sejak terpidana selesai menjalani hukumannya.

3 Putusan Mahkamah Konstitusi Nomor 92/PUU-XIV/2016 ini menyatakan bahwa Pasal 9 Undang -undang Nomor 10 tahun 2016 tentang Perubahan Kedua atas Undang-Undang Nomor 1 Tahun 2015 Tentang Perubahan Atas Undang-Undang Nomor 1 Tahun 2015 Tentang Penetapan Peraturan Pemerintah Pengganti Undang-Undang Nomor 1 Tahun 2014 Tentang Pemilihan Gubernur, Bupati, Dan Walikota Menjadi Undang-Undang, sepanjang frasa "... yang keputusannya bersifat mengikat" bertentangan dengan Undang-Undang Dasar Negara Republik Indonesia Tahun 1945 dan tidak mempunyai kekuatan mengikat. 
Ketua KPU tetap menandatangani Rancangan Peraturan KPU No. 20 Tahun 2018 tersebut yang diantaranya berisi pengaturan mengenai larangan bagi mantan terpidana korupsi menjadi calon legislatif.

Selanjutnya pada tanggal 4 Juni 2018, KPU menyerahkan Rancangan Peraturan KPU No. 20 Tahun 2018 tersebut kepada Menteri Hukum dan Hak Asasi Manusia RI (Menkumham) agar dapat diundangkan dalam Berita Negara Republik Indonesia 4 . Namun Menkumham menolak permohonan awal pengundangan tersebut, dan mengembalikan Rancangan Peraturan KPU No. 20 Tahun 2018 tersebut kepada KPU agar dilakukan sinkronisasi dan penyelarasan ${ }^{5}$. Hal tersebut memang dilakukan Menkumham agar Peraturan KPU yang hendak diundangkan tidak bertentangan dengan peraturan perundang-undangan yang lebih tinggi dan putusan-putusan MK. Namun sikap Menkumham ini mendapatkan sorotan dari berbagai pihak, karena menilai kewenangan pengundangan merupakan kewenangan administratif, dan oleh karena itu Menkumham tidak memiliki kewenangan untuk menilai substansi Rancangan Peraturan KPU yang hendak diundangkan tersebut. Bahkan KPU sempat menyatakan akan memberlakukan Peraturan KPU No. 20 Tahun 2018 tersebut meskipun tidak diundangkan oleh Menkumham.

Meskipun demikian, karena adanya polemik tersebut, para pemangku kebijakan melaksanakan Rapat Konsultasi antara Pimpinan DPR, pemerintah dan penyelenggara pemilu untuk membahas Peraturan KPU No. 20 Tahun 2018 tersebut hingga akhirnya diperoleh kesepakatan, yakni mengubah format larangan bagi mantan terpidana korupsi menjadi calon legislatif, yang semula diatur pada pasal 7 ayat 1 huruf h (yakni terkait persyaratan calon), diubah pengaturannya ke Pasal 4 Ayat (3), Pasal 11 ayat (1) huruf $d$, dan formulir Model B.3 yang pada intinya mewajibkan partai politik untuk tidak menyertakan mantan terpidana bandar narkoba, kejahatan seksual terhadap anak, dan/atau korupsi, dengan cara menandatangani pakta integritas pencalonan dengan menggunakan formulir B.3. Dengan adanya kesepakatan tersebut, akhirnya Menkumham mengundangkan Peraturan KPU No. 20 Tahun 2018 tersebut dalam Berita Negara Republik Indonesia (BNRI) dengan Nomor 834 Tahun 2018 ${ }^{6}$. Namun pada akhirnya Pasal 4 ayat (3), Pasal 11 ayat (1) huruf $d$, dan Lampiran Model B.3 Peraturan KPU No. 20 Tahun 2018 tersebut sepanjang frasa "mantan terpidana korupsi" dibatalkan oleh Putusan Mahkamah Agung Nomor: 46P/HUM/2018, karena dinilai bertentangan dengan peraturan perundang-undangan yang lebih tinggi, yaitu dengan Undang-Undang Nomor 7 Tahun 2017 tentang Pemilihan Umum (UU Pemilu) juncto Undang-Undang

4 Tempo.co, "Tarik-Ulur Larangan KPU Soal Eks Napi Korupsi Jadi Caleg", https://nasional.tempo.co/ read/1102506/tarik-ulur-larangan-kpu-soal-eks-napi-korupsi-jadi-caleg (diakses 20 Juli 2020).

5 Kompas.com, "Kemenkumham Kembalikan PKPU Larangan Eks Koruptor "Nyaleg" ke KPU", https://nasional. kompas.com/read/2018/06/11/15344721/kemenkumham-kembalikan-pkpu-larangan-eks-koruptor-nyalegke-kpu (diakses 20 Juli 2020).

6 Hukum Onine.com, "Begini Poin-Poin Kesepakatan Rapat Konsultasi Pencalonan Terpidana-Jika Uji Materi Ditolak MA, KPU Berhak Mencoret Calon Yang Berstatus Mantan Terpidana", https://www.hukumonline.com/ berita/baca/lt5b3dff57b25a5/begini-poin-poin-kesepakatan-rapat-konsultasi-pencalonan-terpidana (diakses 20 Juli 2020). 
Nomor 12 Tahun 2011 tentang Pembentukan Peraturan Perundang-undangan.

Polemik substansi pengaturan pada Peraturan KPU No. 20 Tahun 2018 tersebut memang telah banyak diulas, namun khusus terkait sikap Menkumham yang menolak permohonan awal pengundangan Peraturan KPU No. 20 Tahun 2018 tersebut belum banyak diulas. Pasal 13 UU Pemilu memang memberikan kewenangan kepada KPU untuk menetapkan Peraturan KPU untuk setiap tahapan Pemilu. Kewenangan menetapkan peraturan ini sama dengan kewenangan lembaga negara independen lainnya dalam menetapkan peraturan, seperti Badan Pemeriksa Keuangan, Komisi Yudisial, Bank Indonesia, KPU, Bawaslu, serta lembaga negara independen lainnya. Peraturan lembaga negara independen tersebut diakui keberadaannya dan mempunyai kekuatan hukum mengikat sepanjang diperintahkan oleh Peraturan Perundang-undangan yang lebih tinggi atau dibentuk berdasarkan kewenangan 7 . Namun untuk dapat mengikat secara umum, maka peraturan lembaga negara independen tersebut harus diundangkan terlebih dahulu ${ }^{8}$. Sesuai dengan Pasal 85 Undang-undang Nomor 12 tahun 2011 Tentang Pembentukan Peraturan PerundangUndangan sebagaimana telah diubah dengan
Undang-Undang Nomor 15 tahun 2019 tentang Perubahan atas Undang-Undang Nomor 12 Tahun 2011 Tentang Pembentukan Peraturan Perundang-Undangan (UU PPP), pengundangan Peraturan Perundangundangan dalam Lembaran Negara Republik Indonesia atau Berita Negara Republik Indonesia dilaksanakan oleh menteri yang menyelenggarakan urusan pemerintahan di bidang hukum ${ }^{9}$.

Kewenangan pengundangan tersebut menurut beberapa pihak merupakan kewenangan administratif, karena sifatnya hanya penempatan peraturan perundangundangan saja, tanpa perlu melakukan pemeriksaan substantif terhadap peraturan perundang-undangan tersebut. Namun menurut Maria Farida, pengundangan lebih dari persoalan administratif, karena pengundangan mempunyai efek bahwa undang-undang tersebut dapat berlaku mengikat umum, sedangkan jika hanya pengesahan saja tidak berlaku mengikat umum $^{10}$. Polemik terkait kewenangan suatu lembaga memang lazimnya dibahas sebagai objekHukum Tata Negara. Namun sebagaimana dijelaskan oleh Van Vollenhoven, bahwa hukum administrasi negara membahas negara dalam keadaan bergerak (state in progress) atau staats in beweging, yakni mempelajari 
segala kewenangan atau aparatur dalam menjalankan proses-proses pemerintahan. Sementara itu, hukum tata negara melihat atau membahas negara dalam keadaan diam (state in still) atau staats in rust ${ }^{11}$. Perkembangan dewasa ini mengenailuas cakupan hukum administrasi negara pada prinsipnya menggabungkan teori residu Van Vollenhoven dengan pendapat Prajudi. Hal tersebut berarti luas cakupan hukum administrasi negara lebih menitikberatkan bidang ilmu, selain yang menjadi bahasan hukum perdata, hukum pidana, dan hukum tata negara, lalu ditambahkan segala hal yang berkaitan dengan masalah prosedur, tata laksana, dan kegiatan administrasi lainnya ${ }^{12}$. Artinya polemik pengundangan Peraturan KPU Nomor 20 Tahun 2018 tersebut sangat relevan untuk ditinjau dari pandangan hukum administrasi negara.

Berdasarkan latar belakang permasalahan tersebut, maka rumusan masalah yang diangkat dalam penulisan ini adalah, pertama: bagaimana konsepsi dan tata cara pengundangan peraturan perundangundangan di Indonesia?, kedua, bagaimana pengundangan peraturan lembaga negara independen di Indonesia?, ketiga: bagaimana pelaksanaan kewenangan Menkumham dalam pengundangan Peraturan KPU Nomor 20 Tahun 2018 ditinjau dari hukum administrasi negara?

\section{B. Metode Penelitian}

Penelitian ini merupakan penelitian hukum denganmetodeyuridis normatif. MenurutPeter Mahmud Marzuki, di dalam penelitian hukum umumnya dikenal beberapa pendekatan penelitian yakni: pendekatan undang-undang (statute approach), pendekatan konseptual (conceptual approach), pendekatan kasus (case approach), pendekatan perbandingan (comparative approach) dan pendekatan sejarah (historical approach) ${ }^{13}$. Adapun tulisan ini menggunakan pendekatan undang-undang (statute approach), pendekatan konseptual (conceptual approach), dan pendekatan kasus (case approach).

Pendekatan perundang-undangan (statute approach) dilakukan dengan menelaah peraturan perundang-undangan yang terkait dengan pembentukan peraturan perundangundangan, administrasi pemerintahan, dan pemilihan umum. Sedangkan pendekatan konseptual (conceptual approach) dilakukan dengan mengkaji konsep-konsep dalam hukum administrasi negara dan ilmu perundang-undangan yang terkait dengan pelaksanaan kewenangan suatu lembaga negara dalam pembentukan peraturan perundang-undangan. Adapun pendekatan kasus (case approach) dilakukan dengan mengkaji polemik pengundangan Peraturan KPU Nomor 20 Tahun 2018.

11 Dalam bukunya yang berjudul "Thocbecke en het Administratief", Van Vollenhoven menggunakan ukuran lain yang terkenal dengan teori "residu" (sisa). Dikatakan bahwa yang termasuk objek Hukum Administrasi Negara adalah sisa dari semua peraturan hukum nasional sesudah dikurangi hukum Tata Negara materil, hukum perdata materil, dan hukum pidana materil" (Sjamsiar Sjamsuddin, Hukum Administrasi Negara, Setara Press, Malang, 2019, hlm. 20.)

12 Yos Johan Utama, "Pengertian Administrasi Negara dan Hukum Administrasi Negara", Modul 1, hlm. 36, http:// repository.ut.ac.id/3974/1/ADPU4332-M1.pdf (diakses 27 juli 2020).

13 Peter Mahmud Marzuki, Penelitian Hukum (Jakarta: Kencana Media Group, 2014), hlm. 93. 


\section{Pembahasan}

\section{Konsepsi dan Tata Cara Pengundangan}

\section{a) Konsepsi Pengundangan}

Pasal 1 ayat 12 UU PPP mendefenisikan pengundangan sebagai penempatan Peraturan Perundang-undangan dalam Lembaran Negara Republik Indonesia (LNRI), Tambahan Lembaran Negara Republik Indonesia (TLNRI), Berita Negara Republik Indonesia (BNRI), Tambahan Berita Negara Republik Indonesia (TBRNI), Lembaran Daerah, Tambahan Lembaran Daerah, atau Berita Daerah ${ }^{14}$. Dalam bahasa Inggris, pengundangan dikenal dengan istilah promulgation, yang artinya adalah "The order given to cause a law to be executed, and to make It public; it differs from publication"15. Pengundangan merupakan salah satu tahapan dalam pembentukan peraturan perundang-undangan. Sebagai salah satu tahapan, pengundangan wajib dilakukan ketika membentuk suatu peraturan perundang-undangan. Secara konsepsi pengundangan berkaitan dengan daya ikat dan daya laku suatu suatu peraturan perundangundangan.

Setelahsuatu peraturan diundangkan, maka berlaku fiksi hukum yang menyatakan indereen wordt geacht de wet te kennen (setiap orang dianggap mengetahui undang-undang), oleh karena itu, maka tidak dibenarkan menolak penuntutan hukum dengan alasan "tidak tahu akan adanya peraturan tersebut" ${ }^{16}$. Sebagai konsekuensi dari berlakunya fiksi hukum tersebut, maka pembentuk peraturan wajib memberitahukannya kepada masyarakat agar setiap orang mengetahuinya, yakni dalam hal ini dengan cara pengundangan. Selain itu pengundangan juga berkaitan dengan waktu berlaku mengikatnya peraturan tersebut, hal ini sesuai dengan Pasal 87 UU PPP yang menyatakan bahwa Peraturan Perundangundangan mulai berlaku dan mempunyai kekuatan mengikat pada tanggal diundangkan, kecuali ditentukan lain di dalam Peraturan Perundang-undangan yang bersangkutan. Artinya apabila suatu peraturan perundangundangan tidak diundangkan, maka peraturan tersebut tidak memiliki daya ikat kepada masyarakat umum dan tidak memiliki daya laku, oleh karenanya tidak dapat diberlakukan secara umum. Dengan demikian dapat disimpulkan bahwa pengundangan merupakan salah satu tahapan yang penting dalam pembentukan peraturan perundangundangan, oleh karena itu pengundangan wajib dilakukan apabila ingin memberlakukan peraturan perundang-undangan tersebut secara umum.

Pengundangan dilakukan dengan menempatkan peraturan perundangundangan dalam ${ }^{17}$ :

1) Lembaran Negara Republik Indonesia Yakni dalam hal pengundangan terhadap Undang-Undang/Peraturan Pemerintah

14 Pasal 1 ayat 12 Undang-undang Nomor 12 tahun 2011 Tentang Pembentukan Peraturan Perundang-Undangan sebagaimana telah diubah dengan Undang-Undang Nomor 15 tahun 2019 tentang Perubahan atas UndangUndang Nomor 12 Tahun 2011 Tentang Pembentukan Peraturan Perundang-Undangan.

15 Black's Law Dictionary, https://thelawdictionary.org/promulgation/ (diakses 2 Agustus 2020).

16 Andi Yuliani, "Daya Ikat Pengundangan Peraturan Perundang-Undangan", Jurnal Legislasi Indonesia, Vol. 14 No. 04 (2017): 433.

17 Bab IX Undang-undang Nomor 12 tahun 2011 Tentang Pembentukan Peraturan Perundang-Undangan sebagaimana telah diubah dengan Undang-Undang Nomor 15 tahun 2019 tentang Perubahan atas UndangUndang Nomor 12 Tahun 2011 Tentang Pembentukan Peraturan Perundang-Undangan. 
Pengganti Undang-Undang, Peraturan Pemerintah, Peraturan Presiden; dan, Peraturan Perundang-undangan lain yang menurut Peraturan Perundang-undangan yang berlaku harus diundangkan dalam LNRI.

2) Tambahan Lembaran Negara Republik Indonesia;

Yakni dalam hal pengundangan terhadap penjelasan atas Peraturan Perundangundangan yang dimuat dalam LNRI.

3) Berita Negara Republik Indonesia;

Yakni dalam hal pengundangan terhadap Peraturan Perundang-undangan yang menurut Peraturan Perundang-undangan yang berlaku harus diundangkan dalam BNRI.

4) Tambahan Berita Negara Republik Indonesia;

Yakni dalam hal pengundangan terhadap penjelasan Peraturan Perundangundangan yang dimuat dalam BNRI.

5) Lembaran Daerah;

Yakni dalam hal pengundangan terhadap Peraturan Daerah Provinsi dan Peraturan Daerah Kabupaten/Kota.

6) Tambahan Lembaran Daerah; atau Yakni dalam hal pengundangan terhadap Peraturan Perundang-undangan yang dimuat dalam Lembaran Daerah.

7) Berita Daerah.

Yakni dalam hal pengundangan terhadap Peraturan Gubernur dan Peraturan Bupati/ Walikota.

Adapun peraturan pelaksana terkait pengundangan diatur pada Peraturan Presiden Nomor 87 Tahun 2014 Tentang Peraturan Pelaksanaan Undang-Undang Nomor 12 Tahun 2011 Tentang Pembentukan Peraturan Perundang-Undangan (Perpres 87 tahun 2014), dan Peraturan Menteri Hukum dan Hak Asasi Manusia Nomor 16 Tahun 2015 Tentang Tata Cara Pengundangan Peraturan Perundang-Undangan dalam Lembaran Negara Republik Indonesia, Tambahan Lembaran Negara Republik Indonesia, Berita Negara Republik Indonesia, dan Tambahan Berita Negara Republik Indonesia, sebagaimana telah diubah dengan Peraturan Menteri Hukum Dan Hak Asasi Manusia Nomor 31 Tahun 2017 Tentang Perubahan Atas Peraturan Menteri Hukum dan Hak Asasi Manusia Nomor 16 Tahun 2015 Tentang Tata Cara Pengundangan Peraturan PerundangUndangan dalam Lembaran Negara Republik Indonesia, Tambahan Lembaran Negara Republik Indonesia, Berita Negara Republik Indonesia, dan Tambahan Berita Negara Republik Indonesia (Permenkumham Pengundangan).

\section{b) Tata Cara Pengundangan}

UU PPP memang tidak mengatur secara komprehensif terkait tata cara pengundangan. Sementara Perpres 87 tahun 2014 hanya mengatur tentang syarat suatu peraturan perundang-undangan untuk dapat diundangkan, yakni permohonan pengundangan yang disertai dengan 2 (dua) naskah asli dan 1 (satu) softcopy naskah asli. Adapun pengaturan lebih teknis terkait tata cara pengundangan ini diatur pada Permenkumham Pengundangan. Tahapan pengundangan diawali dengan permohonan pengundangan yang diajukan secara tertulis dan ditandatangani oleh menteri yang menyelenggarakan urusan pemerintahan di bidang kesekretariatan negara atau pimpinan lembaga yang berwenang (dalam hal pengundangan pada LNRI dan TLNRI), dan oleh 
Sekretaris Jenderal/nama lain atau pimpinan tinggi madya yang melaksanakan tugas dan fungsi di bidang peraturan perundangundangan (dalam hal pengundangan pada BNRI dan TBNRI). Permohonan pengundangan tersebut disampaikan kepada Menteri melalui Direktur Jenderal Peraturan Perundangundangan Kemenkumham.

Selanjutnya atas pengajuan permohonan tersebut dilakukan pemeriksaan oleh Direktur Jenderal Peraturan Perundangundangan. Pemeriksaan terhadap permohonan pengundangan yang akan ditempatkan di LNRI dan TLNRI mencakup pemeriksaan kelengkapan dokumen dan pemeriksaan kesesuaian antara naskah asli dengan soft copy naskah asli (pemeriksaan administratif). Sedangkan pemeriksaan terhadap permohonan pengundangan yang akan ditempatkan di BNRI dan TBNRI, selain dilakukan pemeriksaan administratif juga dilakukan pemeriksaan terhadap substansi dan prosedur ${ }^{18}$. Pemeriksaan substansi dan prosedur tersebut dilakukan terhadap lampiran analisis kesesuaian antara Peraturan Perundang-undangan yang akan diundangkan dengan Peraturan Perundang-undangan yang setingkat, Peraturan Perundangundangan yang lebih tinggi, dan/atau putusan pengadilan ${ }^{19}$.

Dalam hal hasil pemeriksaan permohonan pengundangan dinyatakan lengkap maka peraturan Perundang-undangan yang akan diundangkan dicatat dalam buku register Pengundangan dan diberikan tanda terima permohonan sebagai bukti penerimaan pengajuan permohonan Pengundangan. Namun jika tidak lengkap maka Direktur Jenderal Peraturan Perundang-undangan mengembalikan secara tertulis permohonan pengundangan kepada pejabat yang berwenang dari instansi yang bersangkutan disertai dengan alasan. Selanjutnya jika berdasarkan hasil pemeriksaan terdapat permasalahan, maka Direktur Jenderal Peraturan Perundang-undangan melakukan klarifikasi kepada pimpinan instansi yang bersangkutan, serta dapat mengundang kementerian/lembaga, pihak terkait, dan/ atau tenaga ahli untuk mendapatkan masukan dan melakukan sinkronisasi dengan Peraturan Perundang-undangan yang setingkat, Peraturan Perundang-undangan yang lebih tinggi, dan/atau putusan pengadilan. Namun jika tidak terdapat permasalahan, Direktur Jenderal Peraturan Perundang-undangan melakukan:

a. Penyampaian naskah asli Peraturan Perundang-undangan yang akan ditempatkan dalam LNRI dan TLNRI kepada Menteri untuk memperoleh tanda tangan; atau

b. Penandatanganan naskah asli Peraturan Perundang-undangan yang akan ditempatkan dalam BNRI dan TBNRI.

Selanjutnya Naskah asli Peraturan Perundang-undangan yang telah ditandatangani tersebut diundangkan dengan:

a. Mencantumkan nomor dan tahun Lembaran Negara Republik Indonesia dan

18 Pemeriksaan substansi ini banyak diperdebatkan oleh berbagai kalangan, karena dianggap memperluas persyaratan pengundangan sebagaimana diatur pada UU PPP dan Perpres 87 tahun 2014..

19 Dengan adanya Pemeriksaan substansi dan prosedur tersebut, maka dalam hal permohonan pengundangan yang akan ditempatkan di BNRI dan TBNRI, pemohon perlu menyampaikan analisis kesesuaian antara Peraturan Perundang-undangan yang akan diundangkan dengan Peraturan Perundang-undangan yang setingkat, Peraturan Perundang-undangan yang lebih tinggi, dan/atau putusan pengadilan. 
Berita Negara Republik Indonesia; dan/ atau

b. Mencantumkan nomor Tambahan Lembaran Negara Republik Indonesia dan Tambahan Berita Negara Republik Indonesia.

Setelah diundangkan Direktur Jenderal Peraturan Perundang-undangan menyampaikan naskah asli Peraturan Perundangundangan yang telah diundangkan dalam LNRI dan TLNRI kepada menteri yang menyelenggarakan urusan pemerintahan di bidang kesekretariatan negara atau pimpinan lembaga yang berwenang, sedangkan naskah asli peraturan perundang-undangan yang telah diundangkan dalam BNRI dan TBNRI disampaikan kepada Pemrakarsa Peraturan Perundang-undangan. Kemudian tahapan selanjutnya adalah penerbitan LNRI, TLNRI, BNRI, dan TBNRI. Direktur Jenderal Peraturan Perundang-undangan menerbitkan LNRI, TLNRI, BNRI, TBNRI dalam bentuk lembaran lepas sebagai dokumen resmi negara dalam jangka waktu paling lambat 14 (empat belas) hari terhitung sejak tanggal Peraturan Perundang-undangan tersebut diundangkan, untuk kemudian dimuat dalam sistem informasi peraturan perundang-undangan yang dikelola oleh Direktur Jenderal Peraturan Perundang-undangan.

Sebagaimana diuraikan di atas, Permenkumham Pengundangan memang membedakan prosedur pengundangan pada terhadap peraturan perundang-undangan yang ditempatkan pada LNRI dan TLNRI, serta pengundangan terhadap peraturan perundang-undangan yang ditempatkan pada BNRI dan TBNRI. Perbedaan mendasarnya adalah adanya pengaturan terkait pemeriksaan substantif terhadap permohonan pengundangan yang diajukan untuk ditempatkan dalam BNRI dan TBNRI. Adapun alasan dibalik adanya pengaturan pemeriksaan substantif ini adalah untuk mencegah lahirnya peraturan perundangundangan yang tumpang tindih atau disharmoni atau bertentangan Perundangundangan yang setingkat, Peraturan Perundang-undangan yang lebih tinggi, dan/atau putusan pengadilan. Hal ini dapat disimpulkan dari pengaturan pada Pasal 9 ayat 3 Permenkumham Pengundangan tersebut, yang juga sejalan dengan semangat harmonisasi peraturan perundang-undangan sebagaimana diatur pada Peraturan Menteri Hukum dan Hak Asasi Manusia Nomor 23 tahun 2018 tentang tentang Pengharmonisasian Rancangan Peraturan Menteri, Rancangan Peraturan Lembaga Pemerintah Nonkementerian, atau Rancangan Peraturan dari Lembaga Nonstruktural oleh Perancang Peraturan Perundang-undangan.

Tujuan pemeriksaaan substantif pada Permenkumham Pengundangan ini memang sangat baik, namun secara logika administrasi pemerintahan pemeriksaan substantif ini seharusnya hanya dapat diberlakukan pada lingkup pemerintahan yang masih merupakan cabang dari kekuasaan eksekutif saja, sedangkan pada cabang kekuasaan di luar eksekutif, khususnya pada lembaga negara independen, pengaturan tersebut dinilai kurang tepat karena dianggap mencampuri wilayah kekuasaan lain di luar lingkup kekuasaannya. Sebagai perbandingan, independent regulatory agencies (IRA) di Prancis dikenal sebagai pembentuk peraturan sekunder, karena kekuasaannya dibatasi dengan kekuasaan pemerintah atau menteri. Sedangkan IRA di Amerika dapat membentuk 
peraturan tanpa persetujuan presiden, namun ada mekanisme veto kongres yang dapat membatalkan peraturan sebelum diberlakukan ${ }^{20}$.

Sementara lembaga negara independen di Indonesia dapat menerbitkan peraturan tanpa persetujuan eksekutif ataupun legislatif. Sebagai ilustrasi, dalam membentuk suatu peraturan awalnya KPU diwajibkan untuk melakukan konsultasi yang sifatnya mengikat, namun Putusan Mahkamah Konstitusi Nomor 92/PUU-XIV/2016 membatalkan sifat mengikatnya kesimpulan rapat konsultasi tersebut. Mahkamah Konstitusi berpendapat bahwa apabila pelaksanaan wewenang pembentukan peraturan oleh lembaga pemegang delegasi pengaturan tersebut dinilai menyimpang dari apa yang diatur oleh Undang-undang, mekanisme judicial review-lah yang akan menjadi alat kontrol dan lembaga lain tidak boleh mengintervensi materi atau substansi peraturan yang dimaksud $^{21}$. Dengan demikian pemeriksaan substantif dalam pengundangan seharusnya hanya dilakukan pada lingkup pemerintahan yang masih merupakan cabang dari kekuasaan eksekutif saja. Namun hingga saat ini pengaturan tentang pemeriksaan substantif pada Permenkumham Pengundangan tersebut masih berlaku atau tidak dibatalkan oleh Mahkamah Agung, sehingga tetap menjadi prosedur yang wajib dilakukan dalam pengundangan suatu peraturan perundangundangan yang akan ditempatkan pada BNRI dan TBNRI.

\section{Pengundangan Peraturan Lembaga Negara Independen}

Menurut Zainal Arifin Mochtar, ada delapan ciri Lembaga Negara Independen di Indonesia, yaitu bukan cabang kekuasaan utama, pemilihan pimpinan dengan seleksi, pemilihan dan pemberhentian berdasar aturan, proses deliberasi kuat, kepemimpinan kolektif dan kolegial, kewenangan devolutif untuk self regulated, dan legitimasi dari undang-undang. Berdasarkan data yang diformulasikan dari Firmansyah Arifin, dkk (2005), Kementerian Negara PAN, dan Naskah Amandemen Undang-Undang Dasar 1945, Kelompok DPD di MPR (2008), hingga tahun 2009 Indonesia sedikitnya telah memiliki 14 lembaga negara independen, yang bukan merupakan perpanjangan dari salah satu organ kekuasaan tertentu, yakni ${ }^{22}$ :

1) Komisi Yudisial (KY);

2) Komisi Pemilihan Umum (KPU);

3) Komisi Nasional Hak Asasi Manusia (Komnas HAM);

4) Komisi Nasional Anti Kekerasan Terhadap Perempuan (Komnas Perempuan);

5) Komisi Pengawas Persaingan Usaha (KPPU);

6) Ombudsman Republik Indonesia (ORI);

7) Komisi Penyiaran Indonesia (KPI);

8) Komisi Pemberantasan Tindak Pidana Korupsi (KPK);

9) Komisi Perlindungan Anak (KPA);

10)Dewan Pers;

11)Dewan Pendidikan;

12)Pusat Pelaporan dan Analisis Transaksi Keuangan (PPATK);

20 Dominique Custos, "The Rulemaking Power of Independent Regulatory Agencies", The American Journal of Comparative Law (2006): 10-11.

21 Putusan Mahkamah Konstitusi Nomor 92/PUU-XIV/2016, hlm. 77.

22 Bunyamin Alamsyah dan Uu Nurul Huda, "Politik Hukum Pelembagaan Komisi-Komisi Negara dalam Sistem Ketatanegaraan Indonesia", Jurnal Hukum dan Peradilan, Volume 2 Nomor 1 (2013): 100. 
13) Komisi Informasi;

14)Badan Pengawas Pemilu (Bawaslu) ${ }^{23}$.

Jika dilihat dari fungsinya, di antara lembaga-lembaga tersebut ada yang menjalankan fungsi administratif, fungsi regulatif, fungsi ajudikatif, fungsi pengawasan, fungsi pertimbangan, ataupun campuran dari kelimanya. Khusus terkait fungsi regulatif, peraturan yang dibentuk oleh lembaga independen tersebut diakui keberadaannya sebagai suatu jenis peraturan perundangundangan ${ }^{24}$. Pengakuan tersebut diatur pada Pasal 8 ayat (1) UU PPP, yang menyatakan bahwa terdapat jenis peraturan lain selain jenis peraturan perundang-undangan yang diatur pada Pasal 7 ayat 1 UU PPP, yakni mencakup peraturan yang ditetapkan oleh Badan Pemeriksa Keuangan, Komisi Yudisial, Bank Indonesia, lembaga atau komisi yang setingkat yang dibentuk dengan UndangUndang atau Pemerintah atas perintah Undang-Undang, DPRD Provinsi, Gubernur, DPRD Kabupaten/Kota, Bupati/Walikota, Kepala Desa atau yang setingkat. Dengan demikian seluruh peraturan lembaga negara independen masuk dalam kategori peraturan jenis lain pada Pasal 8 ayat (1) UU PPP tersebut.

Sebagai suatu peraturan perundangundangan, maka peraturan lembaga negara independen juga perlu diundangkan. Pengundangan peraturan lembaga negara independen ini memang tidak diatur secara seragam dalam UU PPP maupun peraturan pelaksananya, sehingga tidak terjadi keseragaman bentuk pengundangannya. Setidaknya ada 3 kondisi peraturan lembaga negara dilihat dari kacamata pengundangan:

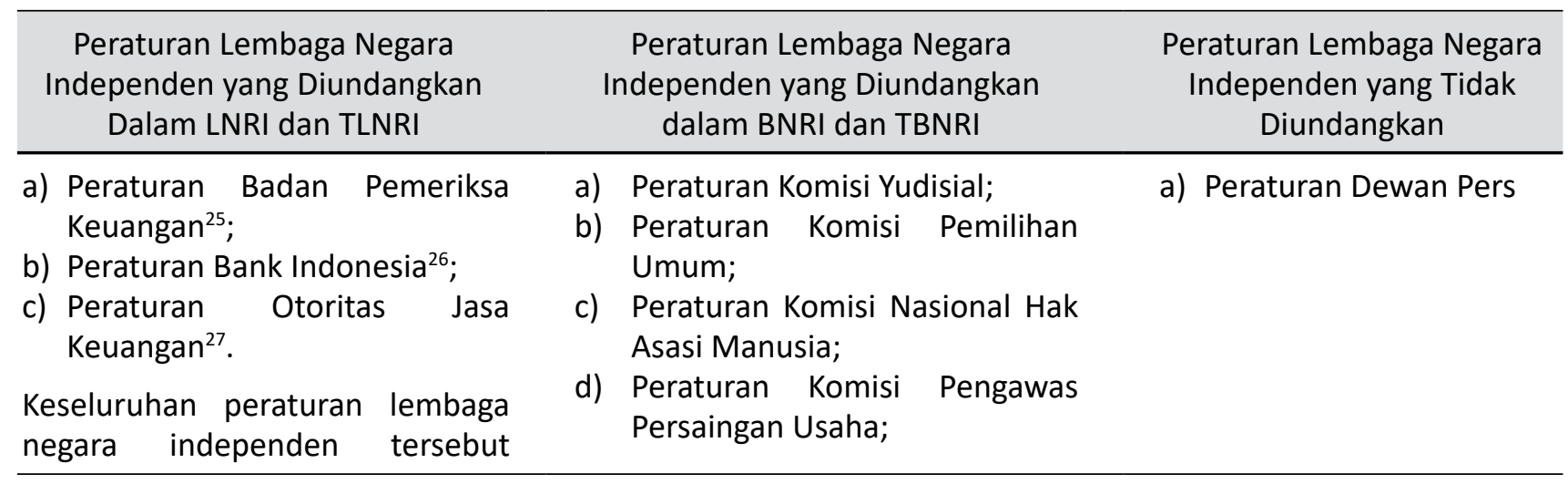

23 Dalam perkembangannya, jumlah ini bertambah dengan dibentuknya Otoritas Jasa Keuangan (OJK) dan Dewan Kehormatan Penyelenggara Pemilu (DKPP), yang juga dapat dikategorikan sebagai lembaga independen yang bukan merupakan perpanjangan dari salah satu organ kekuasaan tertentu.

24 Berdasarkan penelusuran mandiri yang dilakukan, Komisi Nasional Anti Kekerasan Terhadap Perempuan (Komnas Perempuan), Komisi Perlindungan Anak (KPA), dan Dewan Pendidikan, dalam praktiknya tidak menjalankan fungsi regulatif.

25 Pasal 1 angka 17 Undang-Undang Nomor 15 Tahun 2006 Tentang Badan Pemeriksa Keuangan mengatur bahwa Peraturan BPK adalah aturan hukum yang dikeluarkan oleh BPK yang mengikat secara umum dan dimuat dalam Lembaran Negara Republik Indonesia.

26 Pasal 1 angka 8 Undang-undang Nomor 23 tahun 1999 tentang Bank Indonesia mengatur bahwa Peraturan Bank Indonesia adalah ketentuan hukum yang ditetapkan oleh Bank Indonesia dan mengikat setiap orang atau badan dan dimuat dalam Lembaran Negara Republik Indonesia.

27 Pasal 1 angka 11 Undang-Undang Nomor21 Tahun 2011 tentang Otoritas Jasa Keuangan mengatur bahwa Peraturan OJK adalah peraturan tertulis yang ditetapkan oleh Dewan Komisioner, mengikat secara umum, dan diundangkan dalam Lembaran Negara Republik Indonesia. 
Peraturan Lembaga Negara Independen yang Diundangkan Dalam LNRI dan TLNRI
Peraturan Lembaga Negara Independen yang Diundangkan dalam BNRI dan TBNRI
d) Peraturan Komisi Pengawas Persaingan Usaha;
e) Peraturan Ombudsman Republik Indonesia; Pemberantasan Tindak Pidana Korupsi;
f) Peraturan Komisi
g) Peraturan Pusat Pelaporan dan Analisis Transaksi Keuangan;
h) Peraturan Komisi Informasi;
i) Peraturan Badan Pengawas Pemilu;
j) Peraturan Dewan Kehormatan Penyelenggara Pemilu;
k) Peraturan Komisi Penyiaran Indonesia.

Peraturan Lembaga Negara Independen yang Tidak Diundangkan

a) Peraturan Dewan Pers memang diatur secara khusus
pengundangannya oleh undangundang yang mengatur mengenai lembaga tersebut.

Kondisi lain yang menarik untuk dicermati adalah adanya peraturan lembaga negara yang tidak diundangkan, yakni Peraturan Mahkamah Konstitusi (PMK). Meskipun Mahkamah Konstitusi bukan merupakan lembaga negara independen sebagaimana dimaksud dalam penulisan ini, namun praktik tidak diundangkannya PMK juga menarik untuk dicermati. Berdasarkan Perpres 87 tahun 2014, PMK harusnya diundangkan dalam Berita Negara. Namun hingga tahun 2018 Mahkamah Konstitusi telah menetapkan sebanyak 53 PMK yang seluruhnya tidak diundangkan ${ }^{28}$. Praktik yang dilakukan MahkamahKonstitusi inisempatakan dijadikan rujukan oleh KPU pada saat Menkumham menolak permohonan awal pengundangan Peraturan KPU No. 20 Tahun 2018. Praktik tidak mengundangkan peraturan yang telah ditetapkan, sebagaimana dilakukan oleh MK dan Dewan Pers tersebut hendaknya perlu disudahi, karena menimbulkan kontradiksi dalam sistem perundang-undangan.

\section{Pelaksanaan Kewenangan Menkumham dalam Pengundangan Peraturan KPU Nomor 20 Tahun 2018 ditinjau dari Hukum Administrasi Negara}

Kewenangan adalah kekuasaan formal yang diberikan oleh Undang-Undang atau dari kekuasaan eksekutif administrasi ${ }^{29}$. kewenangan berasal dari kata dasar wewenang yang diartikan sebagai hal berwenang, hak dan kekuasaan yang dipunyai untuk melakukan sesuatu. Menurut Ateng Ateng Syafrudin di dalam kewenangan terdapat wewenang-wewenang (rechtsbe 
voegdheden $)^{30}$. Wewenang merupakan lingkup tindakan hukum publik, lingkup wewenang pemerintahan, tidak hanyameliputi wewenang membuat keputusan pemerintah (bestuur), tetapi meliputi wewenang dalam rangka pelaksanaan tugas, dan memberikan wewenang serta distribusi wewenang utamanya ditetapkan dalam peraturan perundang-undangan ${ }^{31}$. Lebih lanjut Bagir Manan sebagaimana dikutip oleh Ridwan HR berpendapat bahwa wewenang dalam bahasa hukum tidak sama dengan kekuasaan (macht). Kekuasaan hanya menggambarkan hak untuk berbuat atau tidak berbuat. Dalam hukum wewenang sekaligus berarti hak dan kewajiban (rechten en plichten) ${ }^{32}$. Artinya adanya suatu wewenang secara otomatis menimbulkan konsekuensi kewajiban bagi pemegang mandat kewenangan tersebut ${ }^{33}$. Demikian halnya dengan kewenangan Menkumham dalam pengundangan peraturan perundang-undangan, yang dapat pula dimaknai sebagai kewajiban Menkumham untuk mengundangkan peraturan perundangundangan.

Kewenangan pengundangan tersebut merupakan kewenangan atribusi yang diberikan oleh Pasal 85 UU PPP. Berdasarkan UU PPP dan Perpres 87 tahun 2014, syarat yang diberlakukan dalam proses pengundangan memang merupakan syarat administratif, karena tidak berkaitan sama sekali dengan substansi peraturan perundangundangan yang akan diundangkan. Namun pada pengaturan lebih teknis, yakni dalam Permenkumham Pengundangan, syarat pengundangan yang tadinya hanya bersifat admnistratif diperluas mencakup pemeriksaan substantif. Hal ini diatur pada Pasal 8, Pasal 9, dan Pasal11A Permenkumham Pengundangan.

Adapun pemeriksaan tersebut dilakukan oleh Direktur Jenderal Peraturan Perundangundangan yang mendapatkan mandat ${ }^{34}$ dari Menteri Hukum dan HAM. Pengaturan dalam Permenkumham Pengundangan tersebut memang sangat dapat diperdebatkan substansinya, namun hingga saat ini Permenkumham Pengundangan tersebut masih berlaku atau tidak dibatalkan oleh Mahkamah Agung, sehingga dapat menjadi dasar hukum bertindak Menkumham dalam menjalankan kewenangan pengundangan.

Sikap Menkumham yang menolak permohonan awal pengundangan Peraturan KPU Nomor 20 Tahun 2018 dengan mengirimkan surat sekaligus mengembalikan draft Peraturan KPU tersebut agar dilakukan sinkronisasi dan penyelarasan, dalam hukum administrasi negara dapat dikategorikan sebagai "tindakan administrasi pemerintahan". Tindakan administrasi pemerintahan adalah perbuatan Pejabat Pemerintahan atau penyelenggara negara lainnya untuk melakukan dan/atau tidak

30 Ateng Syafrudin, "Menuju Penyelenggaraan Pemerintahan Negara yang Bersih dan Bertanggung jawab", Jurnal Pro Justisia Edisi IV, Universitas Parahyangan, Bandung, 2000, hlm. 22.

31 Loc. cit.

32 Ridwan HR, Hukum Administrasi Negara (Jakarta: PT Raja Grafindo Persada, 2013), hlm. 99.

33 Pasal 1 angka 5 Undang-undang Nomor 30 tahun 2014 tentang Administrasi Pemerintahan mendefenisikan wewenang sebagai hak yang dimiliki oleh Badan dan/atau Pejabat Pemerintahan atau penyelenggara negara lainnya untuk mengambil keputusan dan/atau tindakan dalam penyelenggaraan pemerintahan.

34 Pasal 1 angka 24 Undang-undang Nomor 30 tahun 2014 tentang Administrasi Pemerintahan mendefenisikan mandat sebagai pelimpahan Kewenangan dari Badan dan/atau Pejabat Pemerintahan yang lebih tinggi kepada Badan dan/atau Pejabat Pemerintahan yang lebih rendah dengan tanggung jawab dan tanggung gugat tetap berada pada pemberi mandat. 
melakukan perbuatan konkret dalam rangka penyelenggaraan pemerintahan ${ }^{35}$. Roneyn berpendapat bahwa "berstuurhandleling" adalah tiap-tiap tindakan/perbuatan daripada satu alat perlengkapan pemerintahan (berstuurorgaan) baik dalam lapangan Hukum Tata Pemerintahan, maupun di luar Hukum Tata Pemerintahan ${ }^{36}$. Namun perlu diingat bahwa tindakan Administrasi Pemerintahan tersebut harus berdasarkan atas kedaulatan rakyat dan hukum yang merupakan refleksi dari Pancasila sebagai ideologi negara, dan bukan berdasarkan kekuasaan yang melekat pada kedudukan penyelenggara pemerintahan itu sendiri, serta harus sesuai dengan ketentuan peraturan perundang-undangan dan asasasas umum pemerintahan yang baik ${ }^{37}$.

Apabila ditelisik lebih lanjut, memang terdapat beberapa hal yang dapat dijadikan sebagai alasan atas tindakan administrasi Menkumham sebagaimana dimaksud, yakni:

1. Tindakan tersebut dilakukan berdasarkan Pasal 8, Pasal 9, dan Pasal 11A Permenkumham Pengundangan yang merupakan ketentuan lebih lanjut dari Perpres 87 tahun 2014 dan UU PPP;

2. Tindakan tersebut dilakukan karena Peraturan KPU Nomor 20 Tahun 2018 tersebut dinilai bertentangan dengan UU Pemilu dan UU PPP, serta dinilai melawan Putusan Mahkamah Konstitusi Nomor 42/ PUU-XIII/2015;

3. Tindakan tersebut dilakukan untuk mencegah adanya perlakuan diskriminatif terhadap peserta pemilu dalam tahapan penyelenggaraan pemilu.

Tindakan administrasi Menkumham sebagaimana dimaksud tersebutmenimbulkan ketegangan antar lembaga, mengingat KPU merupakan lembaga independen yang kekuasaannya berada di luar kekuasaan eksekutif. Hal ini sejalan dengan pendapat Zainal Arifin Mochtar yang menyatakan adanya serangkaian implikasi substansi yuridis atas kehadiran banyak lembaga negara independen, yakni salah satunya adalah implikasi pada aturan yang dikeluarkan oleh lembaga Negara independen. Kondisi semacam ini tentunya tidak hanya terjadi di Indonesia, ketegangan antara pemerintah dengan lembaga independent juga dialami di Amerika karena adanya keresahan terhadap kualitas peraturan yang dibentuk oleh IRA. Di Amerika ditemukan lebih dari 40 persen peraturan utama dari IRA yang dilaporkan muncul tanpa adanya informasi tentang biaya atau manfaat yang diantisipasi dari peraturan baru tersebut ${ }^{38}$. Bahkan Susan E. Dudley mengatakan bahwa meskipun peraturan yang dikeluarkan oleh IRA memiliki dampak sosial yang luas, analisis yang disajikan sebagai justifikasinya cenderung kurang kuat ${ }^{39}$.

Tindakan administratif Menkumham sebagaimana dimaksud memang dilandasi alasan yang kuat, namun yang perlu diingat bahwa dalam menjalankan kewenangannya,

Pasal angka 8 Undang-undang Nomor 30 tahun 2014 tentang Administrasi Pemerintahan.

Nur Yanto, Pengantar Hukum Administrasi Negara Indonesia (Jakarta: Mitra Wacana Media, 2015), hlm. 77.

Penjelasan umum Undang-undang Nomor 30 tahun 2014 tentang Administrasi Pemerintahan.

38 Cary Coglianese, "Improving regulatory analysis at independent agencies", Rio de Janeiro: Administrative Law Review (2018): 18.

39 Forbes, "Make 'Independent' Regulatory Agencies More Accountable To The Public", https://www.forbes. $\mathrm{com} /$ sites/susandudley/2017/05/09/make-independent-regulatory-agencies-more-accountable-to-thepublic/\#6b24e5137d63 (diakses 8 Agustus 2020). 
Badan atau Administrasi Pemerintahan juga memiliki batasan. Batasannya ${ }^{40}$ adalah:

1) Masa atau tenggang waktu wewenang (onbevoegdheid ratione temporis atau onbevoegheid naar tijd);

2) Wilayah atau daerah berlakunya wewenang (onbevoegdheid ratione loci atau onbevoegdheid naar plaats); dan

3) Cakupan bidang atau materi wewenang (onbevoegdheid ratione materie atau onbevoegheid naar materie).

Bila Pejabat atau Administrasi Pemerintahan tersebut melaksanakan tugasnya tetapi tidak berdasarkan atas Batasan-batasan tersebut, maka yang terjadi adalah menjadi tidak berwenang (onbevoeg) ${ }^{41}$. Apabila ditelisik dari ketiga pembatasan tersebut, maka ulasannya adalah sebagai berikut: Pertama, tidak adanya masa atau tenggang waktu wewenang atas pengundangan peraturan lembaga independen, sehingga tindakan administrasi Menkumham yang secara faktual telah mengakibatkan tertundanya pemberlakukan Peraturan KPU Nomor 20 Tahun 2018 selama kurang lebih 1 bulan $^{42}$, tidak melampaui batasan waktu wewenang. Kedua, tindakan administratif Menkumham sebagaimana dimaksud telah sesuai dengan wilayah berlakunya wewenang tersebut, yakni dalam pengundangan peraturan perundang-undangan pada tingkat pusat. Ketiga, tindakan administratif Menkumham sebagaimana dimaksud tersebut masih dalam cakupan bidang atau materi wewenang, yakni sesuai dengan kewenangan delegatif yang diatur pada Pasal 8, Pasal 9, dan Pasal 11A Permenkumham Pengundangan.

Selanjutnya selain membahas terkait batasan kewenangannya, tindakan administrasi Menkumham sebagaimana dimaksud juga perlu dikaji dari segi etika administrasi publik. Etika administrasi Publik adalah bidang pengetahuan tentang ajaran moral dan asas kelakuan yang baik bagi para administrator pemerintahan dalam menunaikan tugas pekerjaannya dan melakukan tindakan jabatannya ${ }^{43}$. Dalam prakteknya etika administrasi Publik mengacu pada Asas-Asas Umum Pemerintahan yang Baik (AAUPB), yakni meliputi asas: kepastian hukum; kemanfaatan; ketidakberpihakan; kecermatan; tidak menyalahgunakan kewenangan; keterbukaan; kepentingan umum; dan pelayanan yang baik. Apabila ditelisik satu persatu maka hasil analisisnya adalah sebagai berikut:

a. Kepastian hukum

Bahwa Yang dimaksud dengan "asas kepastian hukum" adalah asas dalam negara hukum yang mengutamakan landasan ketentuan peraturan perundangundangan, kepatutan, keajegan, dan keadilan dalam setiap kebijakan penyelenggaraan pemerintahan. Adapun tindakan administrasi Menkumham sebagaimana dimaksud didasarkan pada Pasal 8, Pasal 9, dan Pasal 11A

$40 \quad$ Pasal 15 ayat 1 Undang-undang Nomor 30 tahun 2014 tentang Administrasi Pemerintahan.

41 Harsanto Nursadi, "Tindakan Hukum Administrasi (Negara) Perpajakan yang dapat Berakibat pada Tindakan Pidana", Jurnal Hukum dan Pembangunan (2018): 122.

42 Pemberlakukan Peraturan KPU Nomor 20 Tahun 2018 sempat tertunda selama 1 bulan, yakni sejak ditetapkan dan diajukan kepada Menkumham pada tanggal 4 juni 2018, hingga peraturan KPU tersebut diundangkan pada tanggal 3 Juli 2018.

43 Nina Widowati, dkk, Etika Administrasi Publik dalam Prakteknya (Semarang: Program Studi Doktor Administrasi Publik Press FISIP-UNDIP, 2018), hlm. 247. 
Permenkumham Pengundangan. Oleh karenanya dapat dikatakan bahwa asas ini terpenuhi.

b. Kemanfaatan dan asas kepentingan umum Yang dimaksud dengan "asas kemanfaatan" adalah manfaat yang harus diperhatikan secara seimbang antara: (1) kepentingan individu yang satu dengan kepentingan individu yang lain; (2) kepentingan individu dengan masyarakat. Sedangkan yang dimaksud dengan "asas kepentingan umum" adalah asas yang mendahulukan kesejahteraan dan kemanfaatan umum dengan cara yang aspiratif, akomodatif, selektif, dan tidak diskriminatif. Meskipun beberapa kalangan mendukung rancangan awal Peraturan KPU Nomor 20 Tahun 2018, karena membatasi mantan narapidana koruptor untuk mencalonkan diri menjadi anggota legislatif, namun tindakan administrasi Menkumham sebagaimana dimaksud dilakukan dalam rangka melindungi hak calon peserta pemilu agar tidak mendapatkan perlakuan diskriminatif atau dibatasi haknya tanpa pengaturan Undang-undang dan/atau putusan hakim. Oleh karenanya dapat dikatakan bahwa asas ini terpenuhi.

c. Ketidakberpihakan

Yang dimaksud dengan "asas ketidakberpihakan" adalah asas yang mewajibkan Badan dan/atau Pejabat Pemerintahan dalam menetapkan dan/ atau melakukan Keputusan dan/atau Tindakan dengan mempertimbangkan kepentingan para pihak secara keseluruhan dan tidak diskriminatif. Adapun tindakan administrasi Menkumham sebagaimana dimaksud memang dapat diperdebatkan keberpihakannya. Sebagai bagian dari kekuasaan eksekutif, sulit untuk menampik keberpihakan Menkumham terhadap sikap Mendagri yang pada rapat konsultasi telah jelas menolak substansi pengaturan Peraturan KPU Nomor 20 Tahun 2018 tersebut. Hal ini karena sesungguhnya sikap Menkumham dan Mendagri merupakan gambaran dari sikap kekuasaan pada rumpun yang sama, yakni kekuasaan eksekutif atau Presiden. Oleh karenanya dapat dikatakan bahwa asas ini tidak terpenuhi.

d. Kecermatan

Yang dimaksud dengan "asas kecermatan" adalah asas yang mengandung arti bahwa suatu Keputusan dan/atau Tindakan harus didasarkan pada informasi dan dokumen yang lengkap untuk mendukung legalitas penetapan dan/ atau pelaksanaan Keputusan dan/atau Tindakan sehingga Keputusan dan/atau Tindakan yang bersangkutan dipersiapkan dengan cermat sebelum Keputusan dan/atau Tindakan tersebut ditetapkan dan/atau dilakukan. Adapun tindakan administrasi Menkumham sebagaimana dimaksud telah didasarkan pada hasil pencermatan terhadap pengajuan permohonan pengundangan beserta dengan kelengkapan dokumen yang diajukan oleh KPU, serta pencermatan terhadap substansi rancangan Peraturan KPU Nomor 20 Tahun 2018 tersebut. Oleh karenanya dapat dikatakan bahwa asas ini terpenuhi.

e. Tidak menyalahgunakan kewenangan Yang dimaksud dengan "asas tidak menyalahgunakan kewenangan" adalah asas yang mewajibkan setiap Badan dan/atau Pejabat Pemerintahan tidak 
menggunakan kewenangannya untuk kepentingan pribadi atau kepentingan yang lain dan tidak sesuai dengan tujuan pemberian kewenangan tersebut, tidak melampaui, tidak menyalahgunakan, dan/atau tidak mencampuradukkan kewenangan. Asas ini sudah dibahas pada pembahasan sebelumnya, dan dikatakan bahwa asas ini terpenuhi.

f. Keterbukaan

Yang dimaksud dengan "asas keterbukaan" adalah asas yang melayani masyarakat untuk mendapatkan akses dan memperoleh informasi yang benar, jujur, dan tidak diskriminatif dalam penyelenggaraan pemerintahan dengan tetap memperhatikan perlindungan atas hak asasi pribadi, golongan, dan rahasia negara. Adapun tindakan administrasi Menkumham sebagaimana dimaksud telah disampaikan dengan terbuka, baik secara umum melalui media massa, maupun melalui surat yang ditujukan kepada KPU yang pada intinya mengembalikan rancangan Peraturan KPU Nomor 20 Tahun 2018 agar dilakukan sinkronisasi dan penyelarasan. Oleh karenanya dapat dikatakan bahwa asas ini terpenuhi.

g. Pelayanan yang baik.

Yang dimaksud dengan "asas pelayanan yang baik" adalah asas yang memberikan pelayanan yang tepat waktu, prosedur dan biaya yang jelas, sesuai dengan standar pelayanan, dan ketentuan peraturan perundang-undangan. Adapun tindakan administrasi Menkumham sebagaimana dimaksud dilakukan setelah melakukan pemeriksaan terhadap permohonan pengundangan yang disampaikan oleh KPU. Tindakan tersebut termasuk dalam pelayanan yang baik, karena tidak lama setelah pengajuan permohonan disampaikan, Menkumham segera memproses dan meresponnya. Oleh karenanya dapat dikatakan bahwa asas ini terpenuhi.

Berdasarkan hasil analisis terhadap AAUPB tersebut di atas maka dapat disimpulkan bahwa secara umum tindakan administrasi Menkumham sebagaimana dimaksud masih sesuai dengan AAUPB, meskipun ada asas yang tidak terpenuhi, yakni asas ketidakberpihakan. Terlepas dari pembahasan tersebut di atas, setidaknya ada beberapa catatan yang dapat menjadi pelajaran (lesson learn) atas adanya polemik pengundangan Peraturan KPU Nomor 20 Tahun 2018 tersebut, yakni:

1) Pengaturan tentang pemeriksaan substantif pada Pasal 8, Pasal 9, dan Pasal $11 \mathrm{~A}$ Permenkumham Pengundangan sangat dapat diperdebatkan substansi pengaturannya. Karena pengaturan tersebut seolah menjadi jalan masuk kekuasaan eksekutif untuk mencampuri kewenangan lembaga negara independen untuk membentuk peraturan yang diundangkan pada BNRI dan TBNRI, dalam kasus ini lembaga negara independennya adalah KPU.

2) Kewenangan administrasi pengundangan sesungguhnya lebih tepat dimaknai sebagai kewajiban administrasi pengundangan. Bahkan pada Pasal 73 ayat 2 UU PPP, dalam hal Rancangan Undang-Undang tidak ditandatangani oleh Presiden dalam waktu paling lama 30 (tiga puluh) hari terhitung sejak Rancangan Undang-Undang tersebut disetujui bersama, Rancangan Undang-Undang tersebut sah menjadi Undang-Undang dan 
wajib diundangkan (dicetak tebal oleh penulis). Sikap akhir Menkumham yang mengundangkan Peraturan KPU Nomor 20 Tahun 2018 tersebut, meskipun tidak terdapat perubahan yang signifikan, secara tidak langsung menjadi pengakuan bahwa kewenangan pengundangan peraturan lembaga independen memang dipandang pula sebagai kewajiban yang harus dilaksanakan oleh Menkumham dalam rangka administrasi pemerintahan.

3) Tidakadanya batasan waktu pengundangan peraturan perundang-undangan dalam UU PPP, menjadi salah satu penyebab adanya potensi ketegangan antar lembaga dalam proses pengundangan, khususnya antara Pemerintah dengan lembaga negara di luar cabang kekuasaan eksekutif. Karena berpotensi menyebabkan penyanderaan pelaksanaan kewenangan lembaga lain melalui cara-cara yang mengakibatkan tertundanya pemberlakuan dan sifat mengikat suatu peraturan perundangundangan.

4) Tidak lengkapnya pengaturan terkait syarat dan prosedur pengundangan pada UU PPP juga menyebabkan adanya potensi multi-interpretasi dalam pembentukan peraturan pelaksananya;

5) Dalam menetapkan suatu peraturan, lembaga negara independen (dalam kasus ini KPU) perlu menerapkan asasasas pembentukan peraturan perundangundangan dengan tertib, khususnya asas kesesuaian antara jenis, hierarki, dan materi muatan. Hal ini karena dalam pengujian di Mahkamah Agung, Peraturan KPU Nomor 20 Tahun 2018 nyatanya terbukti bertentangan dengan UU Pemilu dan UU PPP.

\section{Penutup}

Secara konsepsi, pengundangan berkaitan dengan daya ikat dan daya laku suatu suatu peraturan perundang-undangan. Oleh karena itu setiap peraturan perundang-undangan yang dimaksudkan untuk berlaku dan mengikat secara umum wajib diundangkan. Di Indonesia lembaga negara independen dapat membentuk peraturan tanpa persetujuan eksekutif ataupun legislatif. Dalam proses pengundangan pada Lembaran Negara dilakukan pemeriksaan administratif, sedangkan dalam proses pengundangan pada Berita Negara dilakukan pemeriksaan administratif dan substantif. Apabila dilihat dari kacamata pengundangannya, maka setidaknya terdapat 3 kondisi pengundangan peraturan lembaga negara independen, yakni Peraturan lembaga negara independen yang diundangkan dalam LNRI dan TLNRI, Peraturan lembaga negara independen yang diundangkan dalam BNRI dan TBNRI, dan Peraturan lembaga negara independen yang tidak diundangkan. Terkait dengan pengundangan Peraturan KPU Nomor 20 Tahun 2018, apabila ditinjau dari hukum administrasi negara, maka tindakan administrasi Menkumham yang menolak permohonan awal pengundangan Peraturan KPU Nomor 20 Tahun 2018 tersebut bukan merupakan tindakan onbevoeg (tidak berwenang) dan secara umum telah sesuai dengan AAUPB. Namun memang terdapat beberapa catatan yang perlu menjadi perhatian para pemangku kepentingan sebagai pelajaran (lesson learn) dari polemik tersebut.

Oleh karena itu demi menciptakan kejelasan pengaturan terkait tahapan pengundangan, maka Pemerintah dan DPR perlu mengatur persyaratan, tata cara, 
dan batasan waktu pengundangan dengan merevisi UU PPP. Sementara bagi para pemangku kepentingan (khususnya lembaga negara independen) yang merasa berpotensi dirugikan atau terhambat kewenangannya karena Permenkumham Pengundangan tersebut, maka dapat mengajukan uji materi ke Mahkamah Agung apabila diperlukan. Selain itu, demi tertib pembentukan peraturan perundang-undangan, maka praktik tidak mengundangkan peraturan yang sudah ditetapkan perlu diakhiri, karena menimbulkan kontradiksi dalam sistem perundang-undangan.

\section{Daftar Pustaka}

\section{Buku}

Budiardjo, Miriam, Dasar-Dasar Ilmu Politik (Jakarta: PT Gramedia Pustaka Utama, 2007).

Hadjon, Philipus M., Pengantar Hukum Administrasi Indonesia (Yogyakarta: Gadja Mada University Press, 2008).

HR, Ridwan, Hukum Administrasi Negara (Jakarta: PT RajaGrafindo Persada, 2013).

Kumorotomo, Wahyudi, Etika Administrasi Negara (Jakarta: Rajawali Pers, 1992).

Marzuki, Peter Mahmud, Penelitian Hukum (Jakarta: Kencana Media Group, 2014).

Mochtar, Zainal Arifin, Lembaga Negara Independen: Dinamika Perkembangan dan Urgensi Penataannya Kembali Pasca Amandemen Konstitusi (Jakarta: Raja Grafindo Persada, 2016).

Sjamsuddin, Sjamsiar, Hukum Administrasi Negara (Malang: Setara Press, 2019).

Yanto, Nur, Pengantar Hukum Administrasi Negara Indonesia (Jakarta: Mitra Wacana Media, 2015).

Widowati, Nina, dkk, Etika Administrasi Publik dalam Prakteknya (Semarang: Program Studi Doktor Administrasi Publik Press FISIP-UNDIP, 2018).

\section{Makalah / Artikel / Prosiding / Hasil Penelitian}

Alamsyah, Bunyamin, dan Uu Nurul Huda, "Politik Hukum Pelembagaan Komisi-Komisi Negara dalam Sistem Ketatanegaraan Indonesia", Jurnal Hukum dan Peradilan, Volume 2 Nomor 1 (2013).

Chu, Vivian S, dan Daniel T. Shedd, "Presidential Review of Independent Regulatory Commission Rulemaking: Legal Issues", Congressional Research Review (2012).

Coglianese, Cary, "Improving Regulatory Analysis at Independent Agencies", Administrative Law Review (2018).

Custos, Dominique, "The Rulemaking Power of Independent Regulatory Agencies", The American Journal of Comparative Law (2006).

Faiz, Pan Mohamad, "Pengundangan Peraturan Mahkamah Konstitusi", Ruang KonstitusiMajalah Konstitusi No. 140 (2018).

Nursadi, Harsanto, "Tindakan Hukum Administrasi (Negara) Perpajakan yang dapat Berakibat pada Tindakan Pidana", Jurnal Hukum dan Pembangunan (2018).

Syafrudin, Ateng, "Menuju Penyelenggaraan Pemerintahan Negara yang Bersih dan Bertanggung jawab", Jurnal Pro Justisia Edisi IV (2000).

Yuliani, Andi, "Daya Ikat Pengundangan Peraturan Perundang-Undangan", Jurnal Legislasi Indonesia, Vol. 14 No. 04 (2017).

Internet

CNN Indonesia, "Kukuh Larang Eks Koruptor Nyaleg, KPU Siap Hadapi Gugatan", https: / / www.cnnindonesia.com/ nasional/20180523141414-32-300626/ kukuh-larang-eks-koruptor-nyaleg-kpu-siaphadapi-gugatan (diakses 20 Juli 2020).

Tempo.co, Tarik-Ulur Larangan KPU Soal Eks Napi jadi Caleg", https://nasional.tempo.co/ read/1102506/tarik-ulur-larangan-kpu-soaleks-napi-korupsi-jadi-caleg (diakses 20 Juli 2020).

Kompas.com, "Kemenkumham Kembalikan PKPU Larangan Eks Koruptor "Nyaleg" ke KPU", https://nasional.kompas.com/ $\mathrm{read} / 2018 / 06 / 11 / 15344721 /$ kemenkumhamkembalikan-pkpu-larangan-eks-koruptornyaleg-ke-kpu, (diakses tanggal 20 Juli 2020).

Hukum Onine.com, "Begini Poin-Poin Kesepakatan Rapat Konsultasi Pencalonan Terpidana- Jika Uji Materi Ditolak MA, KPU Berhak Mencoret Calon Yang Berstatus Mantan Terpidana", https://www.hukumonline.com/berita/ baca/It5b3dff57b25a5/begini-poin-poin- 
kesepakatan-rapat-konsultasi-pencalonanterpidana (diakses 20 Juli 2020).

Hukum Onine.com, "Maria Farida: Tanpa Pengesahan Presiden, UU Tidak Berlaku", https://www.hukumonline.com/berita/baca/ hol7878/maria-farida-tanpa-pengesahanpresiden-uu-tidak-berlaku, (diakses 25 Juli 2020).

Yos Johan Utama, "Pengertian Administrasi Negara dan Hukum Administrasi Negara, Modul 1", http://repository.ut.ac.id/3974/1/ ADPU4332-M1.pdf (diakses 27 juli 2020).

Black's Law Dictionary, https://thelawdictionary. org/promulgation/ (diakses 2 Agustus 2020).

Forbes, "Make 'Independent' Regulatory Agencies More Accountable To The Public", https://www.forbes.com/sites/ susandudley/2017/05/09/make-independentregulatory-agencies-more-accountable-tothe-public/\#6b24e5137d63 (diakses tanggal 8 Agustus 2020).

\section{Peraturan}

Undang-undang Nomor 23 tahun 1999 tentang Bank Indonesia.

Undang-Undang Nomor 15 Tahun 2006 Tentang Badan Pemeriksa Keuangan.

Undang-undang Nomor 12 tahun 2011 Tentang Pembentukan Peraturan PerundangUndangan.

Undang-Undang Nomor 21 Tahun 2011 tentang Otoritas Jasa Keuangan.

Undang-undang Nomor 30 tahun 2014 tentang Administrasi Pemerintahan.

Undang-Undang Nomor 15 tahun 2019 tentang Perubahan atas Undang-Undang Nomor 12 Tahun 2011 Tentang Pembentukan Peraturan Perundang-Undangan.

Peraturan Presiden Nomor 44 Tahun 2015 tentang Kementerian Hukum dan Hak Asasi Manusia, Menteri.

Peraturan Menteri Hukum dan Hak Asasi Manusia Nomor 16 Tahun 2015 Tentang Tata Cara Pengundangan Peraturan PerundangUndangan Dalam Lembaran Negara Republik Indonesia, Tambahan Lembaran Negara Republik Indonesia, Berita Negara Republik Indonesia, Dan Tambahan Berita Negara Republik Indonesia.

Peraturan Menteri Hukum Dan Hak Asasi Manusia Nomor 31 Tahun 2017 Tentang Perubahan
Atas Peraturan Menteri Hukum Dan Hak Asasi Manusia Nomor 16 Tahun 2015 Tentang Tata Cara Pengundangan Peraturan PerundangUndangan Dalam Lembaran Negara Republik Indonesia, Tambahan Lembaran Negara Republik Indonesia, Berita Negara Republik Indonesia, Dan Tambahan Berita Negara Republik Indonesia.

Peraturan Menteri Hukum dan Hak Asasi Manusia Nomor 23 tahun 2018 tentang tentang Pengharmonisasian Rancangan Peraturan Menteri, Rancangan Peraturan Lembaga Pemerintah Nonkementerian, atau Rancangan Peraturan dari Lembaga Nonstruktural oleh Perancang Peraturan Perundang-undangan.

\section{Putusan Pengadilan}

Putusan Mahkamah Konstitusi Nomor 42/PUU-

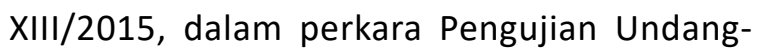
Undang Nomor 8 tahun 2015 tentang Perubahan Atas Undang-Undang Nomor 1 tahun 2015 tentang Penetapan Peraturan Pemerintah Pengganti Undang-Undang Nomor 1 tahun 2014 tentang Pemilihan Gubernur, Bupati, dan Walikota Menjadi Undang-Undang terhadap Undang-Undang Dasar Negara Republik Indonesia Tahun 1945.

Putusan Mahkamah Konstitusi Nomor 92/PUUXIV/2016, dalam perkara Pengujian UndangUndang Nomor 10 tahun 2016 tentang Perubahan Kedua Atas Undang-Undang Nomor 1 tahun 2015 tentang Penetapan Peraturan Pemerintah Pengganti Undang-Undang Nomor 1 tahun 2014 tentang Pemilihan Gubernur, Bupati, dan Walikota Menjadi Undang-Undang terhadap Undang-Undang Dasar Negara Republik Indonesia Tahun 1945.

Putusan Mahkamah Konstitusi Nomor 4/PUUVII/2009, dalam perkara permohonan Pengujian Undang-Undang Nomor 10 Tahun 2008 tentang Pemilihan Umum Anggota Dewan Perwakilan Rakyat, Dewan Perwakilan Daerah, dan Dewan Perwakilan Rakyat Daerah dan Undang-Undang Nomor 12 Tahun 2008 tentang Perubahan Kedua Atas Undang-Undang Nomor 32 Tahun 2004 tentang Pemerintahan Daerah terhadap Undang-Undang Dasar Negara Republik Indonesia Tahun 1945.

Putusan Mahkamah Agung Nomor: 46P/ HUM/2018, dalam perkara Uji Materiil atas 
Pasal 4 ayat (3), Pasal 11 ayat (1) huruf d, dan Lampiran Model B.3 Pakta Integritas Pengajuan Bakal Calon Anggota DPR/DPRD Provinsi/DPRD Kabupaten/Kota, Peraturan Komisi Pemilihan Umum Nomor 20 Tahun
2018 Tentang Pencalonan Anggota Dewan Perwakilan Rakyat, Dewan Perwakilan Rakyat Daerah Provinsi dan Dewan Perwakilan Rakyat Daerah Kabupaten/Kota (Berita Negara Republik Indonesia Tahun 2018 Nomor 834). 